\title{
Designing and Evaluating Collaborative Projects in Learning Communities: Innovative Practices and Strategies
}

\author{
http://dx.doi.org/10.3991/ijac.v9i1.5385 \\ Suma Parahakaran PhD \\ Sathya Sai Academy, Kuala Lumpur, Malaysia
}

\begin{abstract}
This paper highlights a working model that can help build a framework for enhancing collective capacity building through creating a "win- win" situation between sectors such as corporates, universities, policy makers and the public sector. The model emphasizes higher impact educational practices as a desired and achievable learning outcome.
\end{abstract}

The paper provides a short overview of existing challenges and shortcomings of today's E-learning programs and the reasons why there needs to be an integrated approach for all three sectors. Although Open learning resources are available and online learning communities are workable, there are few evidence based research studies of Policy makers using the E-learning platforms as a collaborative tool to network for the betterment of the society. Past research conducted by the research team on e-platforms, revealed findings that there is a wide scope for collaborative projects integrated through e -learning that can contribute to enhance practical skills and gaining knowledge. Currently, the sharing of knowledge is limited and skewed towards academic excellence. At the same time, corporate companies are tight with budgets on areas that can be complemented through student interns. Peer to peer learning and research based learning can benefit both students and corporate companies through the establishment of joint projects. Integration of these learning communities by CSR taken up by corporates then stands to gain in the long term. The platform is then benchmarked for students to serve their communities and become reflective practitioners.

The paper discusses four long-term objectives using learning communities.

They are - :

- Enhancing the capacity of professional learning communities to contribute to society and empower their participants themselves through a research informed experiential approach.

- How corporate social responsibility can gain prominence and be used to capacity build at the local and global level.

- Use of online educational resources for building collective research informed knowledge on critical social issues.

- the ways in which students from tertiary institutions can contribute to solving key challenges in both local and global contexts through strategies that merge their service learning with the health, financial, economic and educational sectors.
The results of the review will establish new grounds with new insights for Government and Policy makers to strengthen economy and upgrade education systems. Ethical and Context based Learning communities will become the crest jewel of any nation.

Index Terms-Corporate Social Responsibility Learning Communities, Policymaking, Tertiary Education.

\section{INTRODUCTION}

This section introduces the existing roles and functions of learning communities, changes required in policies where e-learning programs are concerned and discusses the challenges faced by corporates venturing into social responsibility projects. Furthermore, the research includes a review of what constitutes a professional community. The discussion includes challenges that university faculties face in successfully implementing learning communities and concludes that the growth of these communities may not be successful unless policy changes and reforms are instituted.

\section{A. Learning Communities}

With the world- wide expansion of e-learning programs the body of knowledge produced by these communities has also grown significantly wider. However, to date there have been no specific directions on how these learning communities can or do contribute more to society and individuals as compared to traditional modes of teaching.

Bielaczyc and Collins (1999) argue that the current goal in education seeks excellence through individual pursuit. If learning communities are to be successful, then how do they become successful and in what ways do learning outcomes differ from traditional modes of teaching? How do we channel e-learning communities to include collaboration and networking systems for sustainability? These questions are still unanswered as e-learning must have specific outcomes which are far more beneficial to communities and create important avenues for advancement as compared to traditional ways of teaching. Considerable resources are required to create an e-learning program and hence there must be discrete outcomes and unique benefits which are not obtained through traditional modes of teaching.

Although learning communities at the university level have become powerful platforms for students in both private and public universities, their efficacy levels have not been established yet (Smith, 2001). Smith (2001) 
asserted that there are challenges such as pedagogical issues, changes related to curriculum with regards to student learning as well as the need to meet the needs of students from diverse backgrounds. At another level, there are issues such as the retention and promotion of faculty staff in universities and institutions that implemented wide scale e-learning programmes and online learning communities. As Schaffert and Geser (2008) pointed out while there has been a notion that with the use of ICT, learning would become more student centred and move towards collaborative approach this has not happened as ascertained by educational institutions. As learning moves from individual to a collective voice, the dynamics will have to change or there must be some evidence of reforms happening on a different scale.

Stoll, Bolam, McMohan, Wallace and Thomas (2006) stated that when professional communities increase their collective capacity it would lead to sustainability. In their review of what constitutes a professional learning community, it was noted that there are five shared features; shared values and vision, collective responsibility, reflective professional enquiry and collaboration.

Their reviews also stated that the professional learning communities included value practices such as mutual trust, respect and extension of relationships that go beyond just school members and includes the community in many ways (Stoll et al, 2006). Kabes and Engstrom (2010) based on a qualitative study conducted with students from a Masters Education Program, reported enriched experiences from a Learning Community Program which was introduced with the aim of assisting students to become reflective practitioners.

Similarly, Blitz (2013) reviewed studies of online communities of educators in order to establish whether these educators could achieve the goals of professional learning communities (PLC) by looking at traditional practices for PLC. The review results stated that opportunities maybe provided to teachers to become reflective practitioners and opportunities to collaborate with more flexible time given to them. These studies reveal that in learning communities, there are different requirements compared to traditional modes of teaching. Teachers need to have time for reflection and discussion and the curriculum has to be flexible enough to give time. With the establishment of new learning opportunities such as open educational resources, there are expectations that they will help students to learn faster and result in the establishment of a more knowledgeable community. The teacher directed teaching methods existing in many parts of online learning such as in Asia, become obstacles to form learning communities, especially with lack of time and in terms of space. Malie \& Akir (2012) found that in traditional classrooms lectures (eighty nine in the sample) and explanation (ninety five) were the most favoured learning methods. The other learning methods (reading journals, books, and problem solving) were less popular

\section{B. Role of Policy makers and CSR services}

Brown, Anderson and Murray (2007) conducted a documentary analysis of e-learning policy and strategies from 2000- 2005 across nine countries and six states and provinces.

Their study resonates with issues that are widely prevalent in Asian countries. E-learning initiatives place a greater emphasis on formal education and have not been used to provide access to information of real life issues related to financial and social services, and their study of policy initiatives trigger us to question the actual use of elearning programs. Do e-learning programs address the basic goals of education? Do Educational policy initiatives about e-learning at the tertiary level actually assist students have an education that helps them to achieve the goals of education and citizenship?

Schaffert and Geser's (2008) recommendations for policy makers suggest that students to be provided more access to open educational resources and the collaboration of private and public partnerships in innovative educational practices.

\section{Corporate Social Responsibility (CSR)}

The definition of corporate social responsibility (CSR) is varied. For the purpose of clarity, the author of this paper defines CSR as responsibility that brings honorable progress to the nation beyond its own financial progress and upholds ethical conduct by aligning to Government Policies. CSR is not for companies alone but it is a part of a larger network which benefits itself and the community it serves.

The global online dialogue organized by the joint venture between the World Bank Institute, the Private Sector Development Vice Presidency of the World Bank, and the International Finance Corporation during the E- conference on Public Policy for Corporate Social Responsibility held between July $7-25^{\text {th }}$ in 2003 came up with interesting recommendations and findings. The main objective was to find out how public sectors can support CSR activities and come out with recommendations for Policy makers. The major suggestion was that governments could provide legally functioning structures with proper implementation procedures for public services. By setting up regulatory bodies they could eradicate corruption, bribery and unethical practices, giving incentives to CSR projects through tax benefits, recognizing their work and focusing on the gaps in the current agenda (Petkoski \& Twose, 2003). An important outcome of the dialogue resulted in a suggestion that implementing CSR must be implemented at a local level. In addition, national guidelines for CSR could be developed so they become standards for CSR activities and their performance therefore can be assessed. The discussion also concluded with suggestions for governments to set up a properly functioning regulatory body to lead and enable the smooth running of public services. During the online global discussion, it was suggested that the role of the government should be to develop clear policy objectives and to practice socially responsibility by not giving the legal authority to non- elected private or public bodies. Here, the political justice must over rule other policies set by both private and public policies. However, where political sector is weak the suggestion by the participant was that the civil sector will have to support poor governance.

Aud, Bernstein \& Cashore (2008) stated that CSR services could go beyond the immediate needs of the market. This must ensure that CSR services go beyond enforced rules and regulations of the implemented projects. The goals of CSR must reap long-term benefits and have positive outcomes for stakeholders thus enhancing corporate sustainability (Porter and Kramer, 2006). 
Their review of CSR programs resulted in important findings on evaluation of CSR projects. They stated that the policy innovation and the relationship of the issues must have a direct relationship and the positive impact that CSR issues have must be long term.

Corporates face challenges as they implement their services, as they have to deal with different agents. One of the emerging threads during the conference organized by the joint venture between the World Bank Institute, the Private Sector Development Vice Presidency of the World Bank, and the International Finance Corporation questioned whether the public sectors had the right incentives for actions by different corporates and enterprises. The report from the conference (Petkoski \& Twose, 2003) also stated that there is a positive trend when one links performance and CSR. The discussion findings revealed that for CSR to be successful, the agents, governments and corporates as well as policy makers should be interactively involved (Petkoski \& Twose, 2011).

Do policy initiatives address the importance of collaborative work (Gunn, 1978, Hunter, 2003, Danaher, 2011)? Internationally non- government organisations (NGO's) and joint bodies, commenting on a range of social and community issues have highlighted the negative consequences that result from a lack of collaboration between different sectors (Czikus,2011; United Nations Human Settlements Programme (United Nations Development Programme,2005 [UNHABITAT]; Primary and secondary schools assess children more on individual skills and knowledge outcomes. Consequently, they may leave school without the skills in collaborative work and problem solving required to help solve social and community based issues. While at the tertiary level, e-learning can be used as a tool to help support student learning the acquisition of the more practical skills such as networking skills can significantly help students during their collaborative projects with companies.

\section{Challenges in University e-learning programs}

Increasing numbers of universities globally are integrating online learning into their courses. However, a review of studies suggests that there many obstacles. In China it was reported that staff and educators lacked the knowledge required to develop blended learning courses. Further reviews have also found that while university policies were favourable towards creating student centred learning, administrators and educators had limited potential to change the existing style of teaching. For example the study reported that in Korea, the unstimulating instructional contents in the courses was linked to a lack of interactivity with lecturers or instructionists. Similarly in Japan the e-learning programs retained traditional modes of teaching and simply added video and media content to fulfil the 'blended or online learning component (Tham \& Tham, 2011). Currently there are a number of studies which report on the challenges faced by tertiary level elearning programs and highlight how the limited ways in which e-learning has been implemented that demotivates learners ultimately resulting in high drop- out rates (Yuen, 2011).

A review of a Singapore based e-learning case study conducted by Thanasingam, Soong \& Hu (2011) reported on a blended curriculum model on learning which was conducted via face to face tutorials, workshops and online learning. The review revealed the importance of the work-
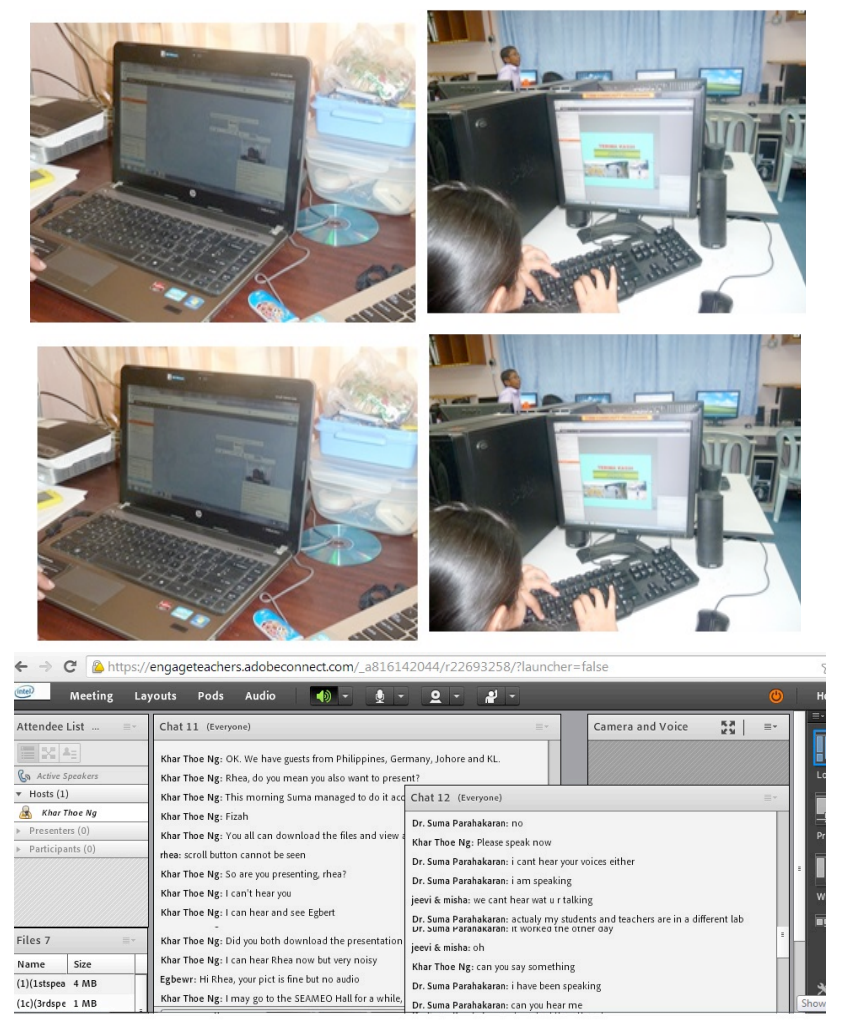

Figure 1. Webinar, Skype and Forums (Source: Printscreen of chat messages with National and International guests, webinar trial run session (Chat 11) $(27 / 2 / 2014)$ and SSYS forum (Chat 12) $(7 / 3 / 2014)$. $\mathrm{Ng}, \mathrm{K} . \mathrm{T}$, Parahakaran, S., Lei Mee, (2014).)

shop sessions, consultations and online sessions in promoting meaningful student centred learning. This smallscale study confirmed that students prefer a combination of learning modes and that online components have to be meaningfully integrated with workshops, feedback sessions, space for peer-to-peer learning and tutoring by facilitators (Thanasingan, Soong \& Hu, 2008).

\section{CONTEXT: LINKING THE GAPS}

Integration of different sectors (policy-makers, corporates, university students and civil society)

\section{A. Research and Education in Malaysia}

When projects with students were initiated by the Regional Centre in Education in Science and Mathematics (RECSAM) in Penang (Ng, 2012), the lesson learnt was that blended learning using constructivist approaches integrated with digital tools will be the future trend $(\mathrm{Ng}$, 2012). The output of the study stressed on the need for engaging students on online platforms with various online digital tools and networking systems so that learning communities become a reality to solve real time issues (Ng, Parahakaran \& Mee, 2015). This is depicted in Fig.1.

\section{B. To make e-learning collaborative}

Blended learning seems to be the most effective learning mode where e-learning is concerned. Universities in China, Korea, Japan and Singapore use blended learning approaches for e-learning (Kwongonn \& Choikit, 2011). However, the researchers reported various limitations to blended learning including lack of pedagogical content, instructional methods and delivery methods. The researchers also found that in Singapore, the interest was 
more on show casing technology enhanced products rather than integrating knowledge based content in e-learning.

\section{Peer tutoring}

To have successful e- learning communities' that work more collaboratively, research suggests peer-to-peer learning could be an effective strategy to ensure student retention. Wenger (2009) asserts that in both the public and private sectors e-learning has involved peer to peer learning and that this strategy is increasingly being used. There are students who network more with their peers and this is an untapped platform with great potential for creating large learning communities. The retention of students in online learning has its success in peer collaboration which can be used as a strategy to increase the learning resources students have access to and to link their practice with real life issues in the communities they live in.

Peer tutoring on an informal basis helps increase skills related to communications, leadership and the social skills required for solving problems in academic education. A study, The effects of reciprocal peer tutoring compared to non- reciprocal peer tutoring conducted in the College of Engineering and Technology, New Era University (Henson,2012) found that reciprocal peer tutoring had the more positive effect on student learning and performance. The study consisted of sixty-eight engineering students enrolled in physics. The students switched roles as tutee and tutor within the ongoing sessions while in the nonreciprocal group, one way peer tutoring was organized. Online peer tutoring was conducted by peer mentors and class monitors in both groups. In both groups, eighty-nine percent felt that there had been a positive impact on their learning as they received help. In addition, the RPT group felt that peer to mentor relationship needed to be enhanced. The non-RPT group responded to a lesser extent (Henson, 2012). Based on this study it appears that peer to peer learning, particularly reciprocal learning, could be used as a strategy to encourage the development of large learning communities which in turn would a help produce large OER.

\section{Evalution of Learning Communities}

Evaluation in education has incorporated a blended approach, which includes both formative and summative approaches. Peer evaluation, use of analytics, and supervision of ongoing work by various experts can lead to engagement with and the development of learning communities.

An evaluation of collaborative projects may include the criteria suggested by Diaz, Brown and Salmons (2010). This includes determining and observing fair distribution of work and requirements, timely reporting on team processes and progress and assessing student effectiveness in addressing issue and resolving problems (Diaz, Brown and Salmons,2010).

The methodology used to integrate the affective domain is through "Service-Learning" / "Community Service" as one of the curricular components. An example of academic service Learning is provided in the url below: (https://www.wcupa.edu/_services/stu.slv/faculty.aspx).

Service learning helps students become reflective practitioners and critical thinkers. A feedback report of the student from the corporates, tertiary educators and the contribution the individual made to society will be a noteworthy way of assessing the affective domain. The impact of student learning for the affective domain has long -term benefits for the self, society and the corporates. The details of the dynamic roles between corporates and student internship will not be discussed here as it is discussed in another review.

\section{PURPOSE}

\section{A. Cases / Samples}

One of the aims of this paper is to highlight that innovative educational policies can support the development of learning communities in partnership corporates, with the goal of finding solutions to pressing societal issues.

There are issues where student skills are inadequate to meet corporate needs while corporates lack long term sustainable relationships with stakeholders and the goodwill of the community because of the continuous competition and ever changing demands of societies we live in. This can be changed if policy makers work with universities and industries to sign agreements negotiating a sustainable and long term contract for the sake of strengthening the nation's economy.

\section{B. Setbacks for team building in Education}

There are threats to team processes (Faidley et al, 2000) and threats to team functioning (Allen and White, 2001). Evaluation of such learning requires collaboration between supervisory levels and peer to peer learning. Dr Maniam Kaliannan (Nottingham University, Business school) and Suseela Devi Chandran (University Technology, MARA) conducted a study on outcome based education and skills required in work places. They found that employers in Malaysia seek from university graduates scientific problem solving skills, communication skills, decision making skills, well developed analytical skills, teamwork skills, well-practiced leadership skills and good interpersonal skills. Malaysia's higher educational institutions in 2012 contained 942000 students of which there were 50000 students from abroad. If industries and corporates provide access to interns for skills and experiential learning, they stand to have a win-win situation whereby students gain experience while corporates and institutions do not have to pay.

The result of the lack of learning communities and free access to education and skills leads to a low economy and education system that is not sustainable. There are issues with online learning which can be complemented by practical learning. An example is the challenge faced by MOOC when Stanford University's Artificial Intelligence course was run. The program faced high dropout rates, lack of a sustainable model and problems related to plagiarism (Siemens, 2013). As learnt from other studies, connectivity to real life issues and peer to peer learning may enhance learning and this would help retain students.

Other e-learning programs currently conducted in Asia such as those in E University, (AeU), Wawasan Open University and Open University Malaysia are examples of higher education institutions that could tap the potential of peer learning. However, the future of online educational institutions will also depend on long term sustainable solutions for updates on the latest mechanisms for online learning and a satisfactory employment rate for students who graduate from these institutions. 


\section{Instructional and Pedagogical contents to link Higher Institutions to internships in Corporates for affective/ citizenship learning}

Currently learning content is designed to accommodate the cognitive domain and does not include educational content that supports affective development in students. This paper emphasizes the importance of integrating contentwhich includes ethics and values (The Asia Pacific Network for International Education and Values Education [UNESCO-APNIEVE], 1998) and considers how content can be taught using collaborative approaches, so that students can learn how to be socially responsible. These platforms which serve large communities aligned with different fields can be strategized to collaborate with the corporate bodies so that students gain direct experience, learning of the affective domain and be part of the projects related to CSR.

For example, if students were to examine how to complete a project on disaster risk situations the knowledge and skill could be obtained via e-learning tools and blended learning exercises that simulate a workplace.

Such a strategy would overcome the reluctance of organisations that work with disaster risk reduction to accommodate for such student learning. This gap divides social life situations and the actual academic and workplace. There are growing educational, health and economic issues in Asian and the African regions, which are related to water and sanitation problems (Czikus, 2011, United Nations Development Programme (UNHABITAT). (n.d.); UNESCO-Earth Charter International (2007); UNHABITAT, 2005; UNHABITAT, 2006; UNHABITAT \& Asian Development Bank, 2003; UNHABITAT \& The African Institute of Sathya Sai Education, 2005). For example, ninety percent of wastewater is discharged untreated in these regions while across the globe eight hundred and eighty four million people have no access clean drinking water (Czikus, 2011). Solving these types of social, economic and health issues requires networking and cooperation from across the various sectors together with focus on local level implementation strategies.

\section{OBJECTIVE}

Based on the review of literature on the status of public policies, CRS and e-learning in tertiary education, this paper proposes that a new model can be formulated for sustainable education. An overview of this model is provided in the remainder of the paper.

Collaboration between academic and corporate bodies will profit in two ways. Firstly the combination of knowledge and skill based activities will enhance student learning. According to Benabout \& Tirole (2009) the demands for individual and corporate social responsibility by societies has gained prominence. If CSR projects are to be successful then, the network between higher institutions and the communities have to grow wider.

The 2009 Corporate Social Responsibility Report stated that the Cisco Networking Academy, for example, uses networking as the core technology instead of separate networks. Ernest Friend, Director of Academic Systems, Florida Community College at Jacksonville vouched that networking academy students have an impact on how they learn (http://www.cisco.com/assets/csr/pdf/CSR Report 2009.pdf.)
A discussion during the global e- conference resulted in many different suggestions on the role of CSR and the public sectors. There were discussions held about whether the integration of social and environmental goals along with shareholder value could be aligned with each other. A concern raised was that this would harm the competitive positions companies hold. This was countered with the suggestion that the companies would gain public goodwill if they include CSR in their long term agenda. Research findings from the US and Europe also reveal that there is a positive relationship between CSR and financial performance (Petkwoski \& Twose, 2003).

Additional concerns were that corporates would not become involved in joint partnerships unless there is some financial gain. However, it was pointed out the focus should be on be long term sustainability rather than short term gains when CSR related projects are included. Long term gains for corporates include gaining the trust of civil society and building the capacity for long term relationship with stakeholders. This enhances the position of corporates and alleviated public doubts that their motivation for CSR is about brand promotion (Petkwoski \& Twose, 2003).

Additionally, corporate companies' with CSR programs are often in situation where they seek support in finding appropriate social issues to be involved in and volunteerism for solving critical issues. This is evident from reports by Porter and Kramer who state that "the prevailing approaches in CSR are so disconnected from business as to obscure many of the greatest opportunities from companies to benefit society" (Porter \& Kramer, 2006, p.2).

The increasing gap in wealth distribution and poverty issues has created avenues for CSR projects. Benabout \& Tirole (2009) asserted that CSR projects could include the need to incorporate a long-term perspective, philanthropic contributions from stakeholders, and individuals asserting their share for altruistic needs for prosocial behaviours. Three important factors affect prosocial behaviors by investors, consumers and workers. They are intrinsic altruism, material incentives (laws and taxes) and social or self-esteem (Benabout \& Tirole, 2009). The use of social media web tools and links with social issues through CSR projects can thus enhance higher order thinking in interns.

\section{METHOD}

Educational policy makers in a given country can link policies related to tertiary education with the committee, which includes representatives from the public, health officials, interns from health and social sciences and educators. Student interns will then have a place in assisting in research and undertaking 'hands on' tasks as part of their practicum in corporate companies as well as assisting them with CSR projects. In addition, these strategies encourage effective marketing processes and enhance advertisement through silent networking without huge financial costs. Consequently, there is an 'inbuilt' benefit to corporates by opening their doors to interns.

It is important that corporate companies network with health, education, urban services and environmental services to work on their CSR programs. Firstly, tertiary education institutions could include community service (service learning) as part of their programs so that students undertake experiential learning on issues relevant within their local contexts. In order that education prepares them 
for developing the nation, free information or knowledge management has become possible with Online Learning Resources (OER). These OER have to be fine-tuned and integrated with a values and ethics course component that focuses on current issues in both local and international contexts. The integration will help community development and enhance social responsibility in citizens.

The review of the different studies from different fields such as social issues, policy making, and tertiary education and CSR projects suggests that a cooperative link between them will strengthen society and benefit each other as well. The issues related to social, economic, health and environmental fields can be supported with peer to peer as well as networking at different levels with Online learning systems. The author suggests a model that would help societies in the long run.

\section{RESULTS}

\section{A. Emerging Model for E-learning}

The model has been formulated in part after reviewing how local NGO's (Malaysia) and community workers have tackled social issues and have been effective. The author admits that her personal volunteer work in society has helped her to see the gaps in the different fields today. This has provided a social insight, which can be linked to sustainable education.

\section{B. Beneficiaries of the Model}

Corporates, University students, Policy Makers, Researchers and Educators, Public and Legal fields, Health, Environmentalists etc. gain to benefit if this model is established.

Tertiary students in many universities are involved service learning and community service. It has become a compulsory subject as well as a need to support society in many ways. However, there is no fixed agenda and universities do not have the time to fix this part of their curriculum nor do they have any local support from policy makers or corporates. On the other hand, corporates do not have fixed areas to give their support unless they benefit their stakeholders. There is hardly any funding available for growing companies and nor do health and social sciences (for example) have enough volunteers to help those at risk or struck by emerging diseases. These scenarios are becoming more common especially with fabricated and natural disasters (recent floods, cyclones, outbreak of diseases, and pollution in waters).

Tertiary level graduates in developing countries often experience unemployment or if employed work in in areas outside of their field of education. Learning in tertiary institutions is very theoretical and the author suggests that this learning becomes practical when students are allowed to work as interns on relevant CSR projects and look into new issues in the companies by researching and working hands on. This will open up new ways of producing evidence based Open Educational resources for the universities in their respective fields. This will require policy makers to work along with university heads and corporate companies of the same field and standard companies. This will help all three sectors to improvise, strengthen relationships and ease their difficulties financially and where progress is required.

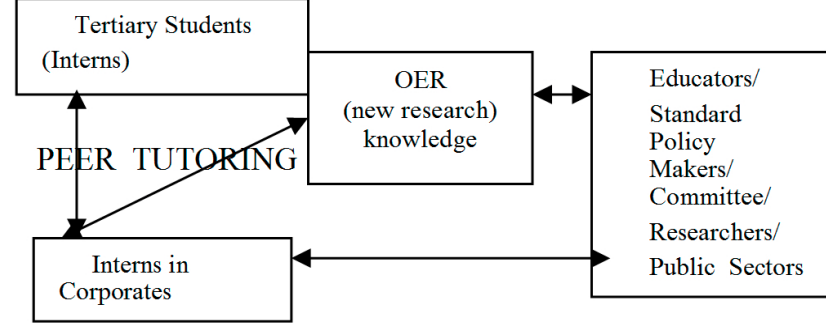

Figure 2. Multi prong approach among sectors

This paper has its limitations, as this is an ongoing study. The challenge posed by precisely how the social, economic, environmental and health issues can be linked to CSR will be the focus of a follow up review and journal paper. The focus is on bringing in a new model, which will provide a mechanism for innovation and progress if it can be implemented. An example of the network that can be established is shown in the following section.

Figure 2 depicts an example of the networking among sectors.

When student interns work with companies on their CSR projects they are undertaking community service and thus become a source of information for contemporary research, updating information for curriculum in the health sciences and to inform policy makers. Students will also be able to informally market and advertise the companies for which they work. This will only be possible if companies extend their assistance to students and earn the appreciation and respect of the broader community. In turn, students because the company has given them this opportunity will become future stakeholders for the company, society and educators. This will involve a complex network but for long term sustainability and for the benefit of the country, policy makers must make the effort to make this happen. There effect will be the development of sustainable practices through beneficial work by companies, alleviation of poverty, youth empowerment, growth of research and updated curriculum and OER.

Figure 3 provides a design that can be adapted to any field of study.

\section{Learning communities, Corporates and Long term Social responsibility}

If companies were proactively and genuinely involved in solving social issues, they would mitigate any negative concerns they create in their own societies and secondly support their stakeholders by providing them with a long term plan (Porter \& Kramer, 2006). According to Porter \& Kramer (2006)global reporting initiatives have become a standard for CSR reporting and have initiated 141 CSR issues (social and environmental). In such cases, where social issues are to be tackled, Schaffert \& Geser (2008) stress that the future of the society as far as knowledge is concerned will require competencies and skills that aim at new educational practices which will depend on open educational resources.

When youth become aware of the issues of concern in their locality, they will be able to build a strong economy for the nation. When power is in few people's hands, there is space for corruption but when power lies in several hands working together, then the nation will be uplifted because of the efforts of many for one national cause. Policy making in any country must take into account the 
sustainability of the economy and the quality of education and hence, an integrated awareness is required to see the total quality outcome. Presently youth are disconnected from skill based learning and the corporates and industry lack in research based workforce while the society is mystified with the ongoing difficulties that are synonymous with what we call a " a developing nation". The integration of the cognitive and affective skill based knowledge of the youth will help a nation become stronger.

Figure 4 illustrates dynamics in learning communities.

To include the affective domain (head, heart and hands), research, practical skills and education needs to be integrated. The quality of research, youth employment, stakeholder satisfaction and the quality of policy making with long-term outputs is the only way to strengthen communities.

As reported by Ex -President of India, Abdul Kalam and Srijan in their reports, industries treat research as a burden and not as an investment. Hence, these sectors, of research and industry have to be combined to increase the economy of any country. In 2012, China's contribution to research and development was 296 billion dollars, which was under $2 \%$ of its gross domestic product while US spent 405 billion dollars, $2.7 \%$ of its gross domestic product. Japan and South Korea spent more, which was 3.7\% and $4.4 \%$ respectively of their gross domestic production and on research and development (Kalam \& Srijan, 2015).

\section{CONCLUSION}

In summary, it is noted that OER resources have the potential to become strong resources when the links are made between the three sectors. The changes that happen as a consequence, as outlined above will benefit all three sectors.

\section{A. Learning Communities}

The model that has been formulated is illustrated in Figure 5.

This innovative combination has the potential to have a positive impact in to any society. Figure 4 illustrates the link between learning communities and the corporate sector. At present, each sector works in isolation support and funding without much youth empowerment. Hence, this model if established can work as an example to guide policy makers, corporates and educators to enable them to work collaboratively. The combination will result in the empowerment of young people and increase the confidence that stakeholders have in the respective corporations with which they deal.

The research based approach and students' direct involvement with the corporate sector will help them learn practical skills and knowledge required. Thus, industries benefit while at the same time increasing their capacity to support marginalized and disadvantaged groups. Currently, tertiary education is quite disconnected from real lifelong learning, such that graduates do not possess the requisite skills and or had the time to understand the social disrupt and adversely affect the development of their respective societies.
Design for E learning communities and linkage to Industries

Educational Policy (integration of e learning in tertiary education as a wide system approach)

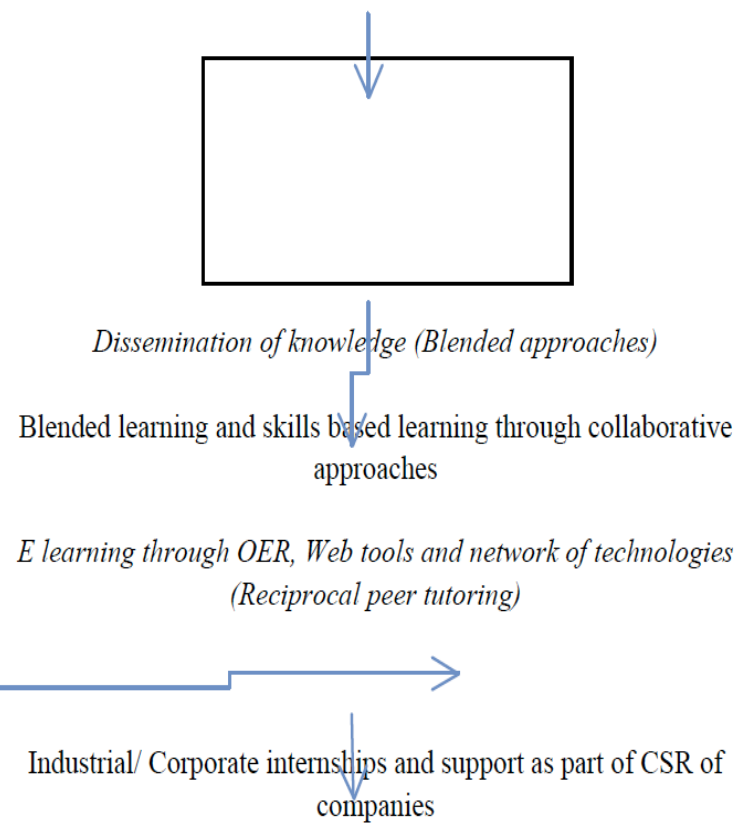

Figure 3. Flow chart illustrating the future trends

Learning Communities

Academic areas

Knowledge Management

(Critical thinking skills)

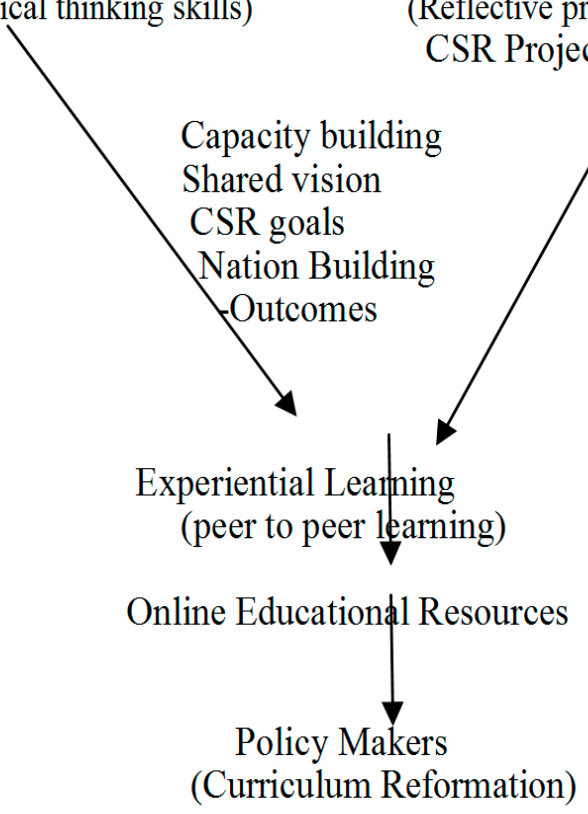

Figure 4. Learning Communities 


\section{Model for future e learning for learning communities}

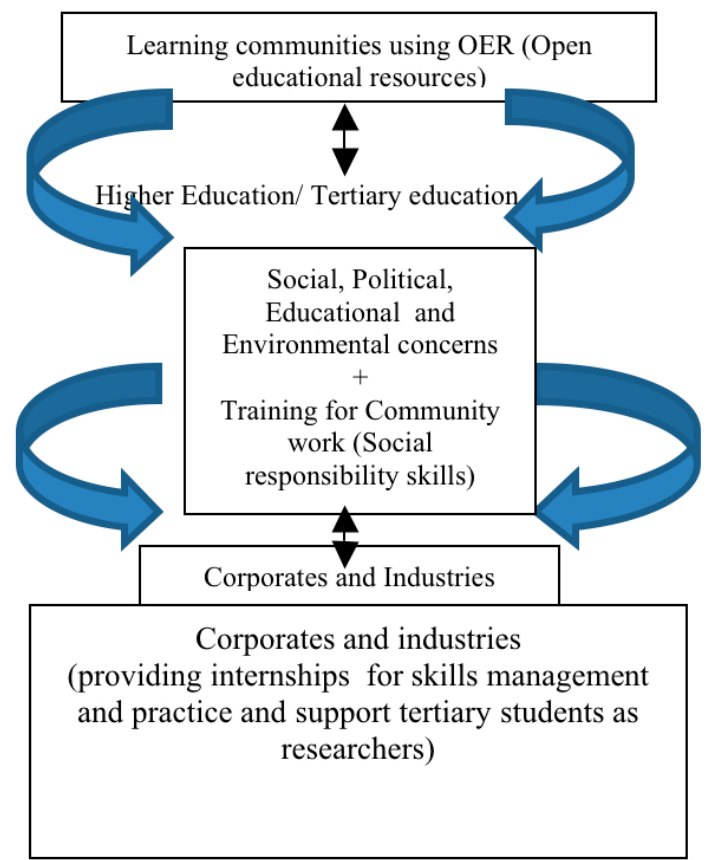

Figure 5. Learning Communities and Corporate Social Responsibility

\section{RECOMMENDATIONS AND OUTLOOK}

1. The critical analysis of studies of e-learning communities presented in this paper has demonstrated that policy making for e-learning is not integrated with other systems, even at the tertiary level. Hence, if educational policies were developed so that they promoted integration of elearning skills based approaches, networking with technological systems and support of CSR programs, all parties gain to profit.

2. Opportunities are limitless if online learning systems become the link to improve the relationship between learning communities and work places. The corporate sector and industrial bodies will benefit from long-term profits and gain social recognition of their community work.

3. There is untapped potential in student interns being involved in research on current issues, which are both meaningful to them and provide opportunities for practical 'hands on' work. This paper recommends that further research be undertaken to target and assess work places and CSR projects that may be suitable for involvement in the implementation of the proposed model.

\section{REFERENCES}

[1] D.E. Allen and H. B. White, III, "Undergraduate group facilitators to meet the challenges of multiple classroom groups", In Duch, B. J., S. E. Groh, and D. E. Allen, eds.. The Power of Problem-Based Learning, pp.79-94. Sterling, VA: Stylus, 2001.

[2] G. Aud, S. Bernstein and B. Cashore, "The new corporate social responsibility", Annual Review of Environment and Resources, 33, pp. 413-435, 2008. http://dx.doi.org/10.1146/annurev.environ. 32.053006.141106

[3] K.Bielaczyc and A. Collins, "Learning communities in classrooms: a reconceptualization of educational practice". In C. M. Reigeluth (Ed.),Instructional-design Theories and Models, a New Paradigm of Instructional Theory, vol. 2, pp. 269-292. Mahwah, NJ: Lawrence Erlbaum Associates, 1999.
[4] R. Benabout, R and J.Tirolez, " Individual and corporate social responsibility". Princeton University .Economica, 77, pp.1-19, 2010. http://dx.doi.org/10.1111/j.1468-0335.2009.00843.x

[5] B. Brown, B. Anderson and F. Murray, "E-learning policy issues: global trends, themes and tensions," [Proceedings ASCILITE Singapore, 2007] http://www.ascilite.org.au/conferences/singapore07/ procs/brown.pdf

[6] Corporate Social Responsibility Report,2009. Retrieved from http://www.cisco.com/web/about/ac227/csr2009/pdfs/CSR 09 So ciety.pdf

[7] A. Czikus, Sustaining the Blue Planet:Global Water Education Conference.Bozeman. Montana, pp.13-17, September, 2011. Retrieved from http://www.projectwet.org/what-we-do/calendar/ events/conferences/sustaining-blue-planet-conference-2011

[8] L.D. Henson, "The effect of reciprocal peer tutoring and nonreciprocal peer tutoring on the performance of students in college physics," Journal of Research in Education, vol.87, pp. 34-49. Manchester University Press, 2012. http://dx.doi.org/10.7227/ $\underline{\text { RIE.87.1.3 }}$

[9] L.A.Gunn, Why is implantation so difficult? Management Services in Government, vol. 33, pp. 169-76, 1978.

[10] D.J.Hunter, Public Health Policy, Cambridge: Polity Press, 2003.

[11] S. Kabes and J. Engstrom, "Student reported growth: success story of a master of science in education learning community program. Insight," A Journal of Scholarly Teaching, vol. 5, pp. 71-81, 2010.

[12] J.J. Faidley, Salisbury-Glennon, J. Glenn, and C. E. Hmelo. . In Evensen, D. H. and C. E. Hmelo, eds. Problem-Based Learning: A Research Perspective on Learning Interactions, 109-135. Mahway, NJ: Erlbaum, 2000.

[13] A.P.J.Kalam .and P.S.Singh, Advantage India : from challenge to opportunity. building the human resource: From Demographic dividend to actual advantage, p.66. HarperCollins Publishers India, 2015.

[14] M. Kaliannan and Chandran, "Empowering students through outcome based education", (OBE). Research in Education. No. 37, Manchester University Press. vol. 87, pp. 50-83. 2012. http://dx.doi.org/10.7227/RIE.87.1.3

[15] Kwong Onn and Choi Kit, "Blended learning: a focus study on Asia. IJCSI International Journal of Computer Science Issues, vol. 8, Issue 2, March 2011 ISSN (Online): 1694-0814 www.IJCSI.org

[16] S. Malie and O. Akir, O, Bridging gaps between learning and reaching through recognition of students' learning approaches: case study. Research in Education, vol.87, Manchester University, 2012. Press. http://dx.doi.org/10.7227/RIE87.1.6

[17] K.T. Ng, Going global in search for science and mathematics researchers (A report of the launching of on-line learning hub and workshop to promote ESD and EFA), 2012. Penang: RECSAM.

[18] K.T. Ng, S. Parahakaran, and Lei Mee, " Enhancing Sustainable Awareness Via SSYS Congress: Challenges and Opportunities of E-platforms to Promote Values-Based Education". International Journal of Educational Science and Research. 2014, IJESRAPR20159.

[19] D. Petkwoski and N. Twose, Public Policy for Corporate Social Responsibility. World Bank Institute, World Bank, IFC and Corporate Social Responsibility and Sustainable Competitiveness. July $7-25,2003$. Retrieved on 12/18/2015 from http://info.worldbank.org/etools/docs/library/57434/publicpolicy econference.pdf.

[20] M.E. Porter and M.R. Kramer, Strategy \& society: The link between competitive advantage and corporate social responsibility. Harvard Business Review, 84 (12), pp.1-14, 2006.

[21] R. Santhiram, S. Parahakaran, and Vighnarajah, "Linking social justice and innovation awareness through distance education for higher educational institutions: a reflective pedagogical and curricular framework for sustainable development". Wawasan University. 2013.

[22] S.Schaffert, and G. Geser, G, Open Educational Resources and Practices.In: $\quad$ eLearning $\quad$ Papers, 7 http://www.elearningeuropa.info/files/media/media14907.pdf.

[23] G. Siemens, Commonwealth of Learning., Open Educational Resources: Innovation, Research and Practice. Massive Open Online Courses: Innovation in Education? Athabasca University.pp.5-4. 2012. 
PAPER

Designing And Evaluating Collaborative Projects in LeARning Communities: InNOvative Practices AND...

[24] B.L.Smith, The challenge of learning communities as a growing national movement. AAC\&U Peer Review 4(1). 2001, Summar Fall.

[25] C. Snelson and P. Elison-Bowers, "Using you tube videos to engage the affective domain in E- Learning" Research, Reflections and Innovations in Integrating ICT in Education, Vol 3 Badajoz, Spain: Formatex, pp.1481-1485, 2009.

[26] K.O. Tham and Tham, C. K, Blended learning - A focus study on Asia. IJCSI International Journal of Computer Science Issues, 8(2), 2001, pp.136-142. ISSN 1694-0814 (Online).

[27] UNESCO-APNIEVE, Learning to live together in peace and harmony: Values education for peace, human rights, democracy and sustainable development for the Asia Pacific Region: A UNESCO-APNIEVE sourcebook for teacher education and tertiary level education. Bangkok: UNESCO PROAP. 1998, Retrieved from http://unesdoc.unesco.org/images/0011/001143/114357eo.pdf

[28] United Nations Development Programme. (n.d.). Millenium development goals. $\quad$ Retrieved from http://www.undp.org/mdg/basics.shtml

[29] United Nations Human Settlements Programme (UNHABITAT), Report on the centralised training workshop. Tanzania: United Nations Human Settlement. 2005.

[30] United Nations Human Settlements Programme (UNHABITAT), Facilitators \& trainers guidebook. Nairobi: United Nations Human Settlements Programme (UNHABITAT), 2006.

[31] United Nations Human Settlements Programme (UNHABITAT) \& Asian Development Bank (ADB), Report of the regional consultations on values-based water education for Asia and the Pacific. Manila, Philippines: United Nations Human Settlements Programme (UNHABITAT), 2003.
[32] United Nations Human Settlements Programme (UNHABITAT) $\&$ The African Institute of Sathya Sai Education, Water for African cities - Phase II. Kenya., 2005. Retrieved from http://www.unhabitat.org

[33] P. Van der Zaag, Water's vulnerable value in Africa. Value of Water Research Report Series 22 of UNESCO-IHE. Retrieved from http://www.waterfootprint.org, 2006.

[34] L.S. Vygotsky, Mind in Society: The Development of Higher Psychological Processes. M. Cole, V. John-Steiner, S. Scribner, and E. Souberman, eds. Cambridge, MA: Harvard University Press, 1978.

[35] A. Yuen, "Exploring teaching approaches in blended learning", Research and Practice in Technology Enhanced Learning, vol. 6, No.1, pp. 3-23, Asia-Pacific Society for Computers in Education. Centre for Information Technology in Education. Hong Kong, China, 2011.

\section{AUTHOR}

Dr Suma Parahakaran was with Wawasan Open University, Penang. She is now with the Sathya Sai Academy (NGO), Kuala Lumpur, Malaysia (email: sumjayan@gmail.com)

This article is an extended and modified version of a paper presented at the the International Conference on E-learning in the Workplace 2015 (ICELW'15), held in June 2015, at Columbia University in New York, NY, USA. Submitted 18 December 2015. Published as resubmitted by the author 13 March 2016. 